\title{
Lung mechanics after cardiac valve replacement
}

\author{
M J MORRIS, M M SMITH, AND B G CLARKE \\ From the Pulmonary Function Laboratory, St Vincent's Hospital, Melbourne, Victoria, Australia
}

\begin{abstract}
Fourteen patients undergoing single aortic or mitral valve replacement had measurements made of lung volumes, static pressure-volume $(\mathrm{P}-\mathrm{V})$ relationships, and conductancepressure relationships during deflation before operation and again between one and two years later. At follow-up, total lung capacity (TLC), functional residual capacity (FRC), residual volume (RV), and static tidal compliance (slope of static P-V deflation line for one litre above FRC) had increased significantly, in association with a decrease in heart size. There was a change in the shape and position of some P-V curves both in the aortic and mitral patients. In the patients with aortic disease $\mathrm{P}-\mathrm{V}$ deflation curves shifted to the left after operation. In the patients with mitral disease the P-V deflation curves before operation crossed those measured after operation, so that at high lung volumes recoil became less after operation, but at low lung volumes recoil increased. Conductance had increased at high lung volumes. The data suggest that in longstanding pulmonary congestion, airways are more rigid making them less distensible at high and less compressible at low transpulmonary pressures than after operation when congestion has been at least partly relieved.
\end{abstract}

The effects of pulmonary congestion on the mechanical properties of the lungs are ideally studied serially in the same subjects. Acute pulmonary congestion has been studied in normal volunteers transfused rapidly, ${ }^{1-3}$ and in patients recovering from acute myocardial infarction. ${ }^{4}$ Chronic pulmonary congestion has been studied before and after mitral valvulotomy. ${ }^{5-8}$ The mechanical disturbances in pulmonary congestion are complex, including effects on airways resistance as well as on compliance, so that interpretation of findings may be difficult. Furthermore in one study ${ }^{6}$ follow-up data have been recorded within a few weeks of surgery when the effects on the lungs of anaesthesia, cardiopulmonary bypass if used, and oxygen breathing may still have been present. This study was, therefore, started with several aims in mind: firstly to study the mechanical properties of the lungs of patients with aortic and mitral valve disease more comprehensively, using deflation conductance-pressure relationships as well as pressure-volume curves to analyse lung mechanics throughout the whole vital capacity; secondly to make follow-up studies after a long convalescent period after valve replacement sur-

Address for reprint requests: Dr MJ Morris, Department of Chest Diseases, Churchill Hospital, Headington, Oxford. gery (one to two years); and thirdly to compare the effects of valve replacement surgery in mitral valve disease with those in aortic disease, in which the period of congestion is generally much shorter and usually milder (though still chronic).

\section{Methods}

Patients were selected simply on the basis that single aortic or mitral valve replacement was planned. The study and its purpose were explained to each patient and consent obtained.

Measurements of lung volumes and lung mechanics were made in 14 patients just before single aortic $(n=6)$ or mitral valve $(n=8)$ replacement, and again one to two years later, (mean interval between studies $18 \cdot 36 \pm 2.25$ SD months). The initial and follow-up studies were made at the same time of day. All pulmonary measurements were taken with patients seated. At the time of the initial study the patients had been resting in hospital for 7-10 days, were receiving carefully determined doses of digoxin and diuretics, and were having intensive physiotherapy. Thus they were all as well as could be achieved by medical treatment. Patients attended the respiratory laboratory as outpatients for the follow-up study. 
Table 1 Clinical details of patients

\begin{tabular}{|c|c|c|c|c|c|c|c|c|c|c|}
\hline Number & Patient & & $\begin{array}{l}\text { Age } \\
\text { (yr) }\end{array}$ & Sex & $\begin{array}{l}B S A \\
\left(m^{2}\right)\end{array}$ & Valve disease & $\begin{array}{l}\text { NYHA } \\
\text { classification } \\
\text { of } \\
\text { dyspneoa }\end{array}$ & $\begin{array}{l}\text { Subiect to } \\
\text { bronchitis }\end{array}$ & $\begin{array}{l}\text { Onset of } \\
\text { dyspnoea: } \\
\text { iime before } \\
\text { study }\end{array}$ & $\begin{array}{l}\text { Known } \\
\text { history of } \\
\text { rheumatic } \\
\text { fever }\end{array}$ \\
\hline 1 & MMcP & $\begin{array}{l}\mathbf{B}^{*} \\
\mathbf{A}^{+}\end{array}$ & 58 & $\mathbf{F}$ & $\begin{array}{l}1 \cdot 71 \\
1 \cdot 71\end{array}$ & Aortic stenosis & $\begin{array}{l}\mathbf{I} \\
\mathbf{I}\end{array}$ & $\begin{array}{l}\text { No } \\
\text { No }\end{array}$ & 0 & No \\
\hline 2 & $\mathbf{A G}$ & $\mathbf{A}$ & 62 & $\mathbf{M}$ & $\begin{array}{l}1.90 \\
1.86\end{array}$ & $\begin{array}{l}\text { Aortic mixed } \\
\text { Stenosis +incompetence }\end{array}$ & I-II & $\begin{array}{l}\text { No } \\
\text { No }\end{array}$ & ? & No \\
\hline 3 & $\mathbf{K H}$ & B & 28 & $\mathbf{M}$ & $\begin{array}{l}1 \cdot 76 \\
1 \cdot 84\end{array}$ & Aortic incompetence & I-II & $\begin{array}{l}\text { Yes } \\
\text { No }\end{array}$ & $8 \mathrm{mo}$ & Yes \\
\hline 4 & $\mathbf{R S}$ & $\begin{array}{l}\mathbf{B} \\
\mathbf{A}\end{array}$ & 59 & $\mathbf{M}$ & $\begin{array}{l}1 \cdot 88 \\
1 \cdot 88\end{array}$ & $\begin{array}{l}\text { Leaking aortic } \\
\text { heterograft }\end{array}$ & I & $\begin{array}{l}\text { No } \\
\text { No }\end{array}$ & $3 \mathrm{mo}$ & No \\
\hline 5 & $\mathbf{B R}$ & $\begin{array}{l}\mathbf{B} \\
\mathbf{A}\end{array}$ & 67 & $\mathbf{M}$ & $\begin{array}{l}1 \cdot 71 \\
1 \cdot 84\end{array}$ & Aortic mixed & III & $\begin{array}{l}\text { No } \\
\text { No }\end{array}$ & $1 \mathrm{yr}$ & No \\
\hline 6 & SI & $\begin{array}{l}\mathbf{B} \\
\mathbf{A}\end{array}$ & 46 & $\mathbf{F}$ & $\begin{array}{l}1 \cdot 52 \\
1 \cdot 56\end{array}$ & Aortic mixed & II & $\begin{array}{l}\text { Yes } \\
\text { No }\end{array}$ & $1 \mathrm{yr}$ & Yes \\
\hline 7 & AK & $\begin{array}{l}\mathbf{B} \\
\mathbf{A}\end{array}$ & 26 & $\mathbf{M}$ & $\begin{array}{l}1.94 \\
1.94\end{array}$ & Mitral mixed & $\begin{array}{l}\text { III } \\
\text { I }\end{array}$ & $\begin{array}{l}\text { Yes } \\
\text { No }\end{array}$ & $3 \mathrm{yr}$ & No \\
\hline 8 & MS & B & 45 & $\mathbf{M}$ & $\begin{array}{l}1 \cdot 69 \\
1 \cdot 69\end{array}$ & Mitral incompetence & $\begin{array}{l}\text { III } \\
\text { I }\end{array}$ & $\begin{array}{l}\text { Yes } \\
\text { No }\end{array}$ & 5 yr & Yes \\
\hline 9 & JS & $\begin{array}{l}\mathbf{B} \\
\mathbf{A}\end{array}$ & 55 & $\mathbf{F}$ & $\begin{array}{l}1.64 \\
1.64\end{array}$ & Mitral incompetence & III & $\begin{array}{l}\text { No } \\
\text { No }\end{array}$ & $1 \mathrm{yr}$ & No \\
\hline 10 & MT & $\begin{array}{l}\mathbf{B} \\
\mathbf{A}\end{array}$ & 61 & $\mathbf{F}$ & $\begin{array}{l}1.57 \\
1.57\end{array}$ & Mitral stenosis & $\begin{array}{l}\text { III } \\
\text { I }\end{array}$ & $\begin{array}{l}\text { No } \\
\text { No }\end{array}$ & 1 yr & No \\
\hline 11 & NS & $\begin{array}{l}\text { B } \\
\text { A }\end{array}$ & 60 & $\mathbf{F}$ & $\begin{array}{l}1.61 \\
1.65\end{array}$ & Mitral mixed & $\begin{array}{l}\text { III } \\
\text { I }\end{array}$ & $\begin{array}{l}\text { Yes } \\
\text { No }\end{array}$ & $24 \mathrm{yr}$ & Yes \\
\hline 12 & JD & $\begin{array}{l}\mathbf{B} \\
\mathbf{A}\end{array}$ & 48 & $\mathbf{F}$ & $\begin{array}{l}1 \cdot 67 \\
1 \cdot 74\end{array}$ & Mitral mixed & $\begin{array}{l}\text { III } \\
\text { I }\end{array}$ & $\begin{array}{l}\text { Yes } \\
\text { No }\end{array}$ & $6 \mathrm{mo}+$ & Probable \\
\hline 13 & $\mathbf{B E}$ & $\begin{array}{l}\mathbf{B} \\
\mathbf{A}\end{array}$ & 58 & $\mathbf{F}$ & $\begin{array}{l}1.67 \\
1.57\end{array}$ & Mitral mixed & $\begin{array}{l}\text { III } \\
\text { II }\end{array}$ & $\begin{array}{l}\text { Yes } \\
\text { No }\end{array}$ & $14 \mathrm{yr}$ & No \\
\hline 14 & DP & $\begin{array}{l}\mathbf{B} \\
\mathbf{A}\end{array}$ & 50 & $\mathbf{F}$ & $\begin{array}{l}1 \cdot 81 \\
1 \cdot 76\end{array}$ & Mitral mixed & $\underset{\text { II }}{\text { III }}$ & $\begin{array}{l}\text { Yes } \\
\text { Yes }\end{array}$ & $3 \mathrm{yr}$ & No \\
\hline
\end{tabular}

* $\mathbf{B}=$ before operation; $\dagger \mathbf{A}=$ after operation.

Table 2 Haemodynamic and radiographic data

\begin{tabular}{|c|c|c|c|c|c|c|c|c|}
\hline Number & Patient & $\begin{array}{l}\text { Mean } \\
\text { pulmonary } \\
\text { artery } \\
\text { pressure }\end{array}$ & $\begin{array}{l}\text { Mean } \\
\text { pulmonary } \\
\text { artery wedge } \\
\text { pressure* }\end{array}$ & $\begin{array}{l}\text { Left } \\
\text { ventricular } \\
\text { pressure }\end{array}$ & $\begin{array}{l}\text { Aortic } \\
\text { pressure }\end{array}$ & $\begin{array}{l}\text { Pul } \\
\text { cons } \\
\text { befo } \\
\text { oper }\end{array}$ & $\begin{array}{l}\text { score } \\
\text { fiter }\end{array}$ & $\begin{array}{l}\text { Heart volume } \\
\text { index } \\
(\mathrm{ml})\end{array}$ \\
\hline 1 & $\mathbf{M M c P}$ & 11 & 5 & $205 / 10$ & $150 / 85$ & - & - & - \\
\hline 2 & $\mathbf{A G}$ & 12 & 4 & $200 / 5$ & $130 / 60$ & $\begin{array}{l}\mathbf{B} \\
\mathbf{A}\end{array}$ & $\begin{array}{l}2 \\
0\end{array}$ & $\begin{array}{l}1435 \\
1144\end{array}$ \\
\hline 3 & $\mathbf{K H}$ & 19 & - & $130 / 20$ & $130 / 45$ & $\begin{array}{l}\mathbf{B} \\
\mathbf{A}\end{array}$ & $\begin{array}{l}2 \\
0\end{array}$ & $\begin{array}{l}1384 \\
1166\end{array}$ \\
\hline 4 & $\mathbf{R S}$ & 28 & 22 & $144 / 54$ & $144 / 64$ & $\begin{array}{l}\text { B } \\
\mathbf{A}\end{array}$ & $\begin{array}{l}3 \\
2\end{array}$ & $\begin{array}{r}1089 \\
986\end{array}$ \\
\hline 5 & $\mathbf{B R}$ & 40 & 21 & $210 / 17$ & $90 / 50$ & $\begin{array}{l}\mathbf{B} \\
\mathbf{A}\end{array}$ & $\begin{array}{l}3 \\
2\end{array}$ & $\begin{array}{r}1626 \\
957\end{array}$ \\
\hline 6 & SI & 18 & 10 & $215 / 5$ & $130 / 65$ & $\begin{array}{l}\mathbf{B} \\
\mathbf{A}\end{array}$ & $\begin{array}{l}2 \\
1\end{array}$ & $\begin{array}{l}771 \\
728\end{array}$ \\
\hline 7 & AK & 29 & 20 & $145 / 0 \cdot 6$ & $145 / 100$ & $\begin{array}{l}\mathbf{B} \\
\mathbf{A}\end{array}$ & $\begin{array}{r}4 \\
-\end{array}$ & $\begin{array}{l}1620 \\
-\end{array}$ \\
\hline 8 & MS & 32 & 23 & $100 / 3-9$ & $100 / 70$ & $\begin{array}{l}\mathbf{B} \\
\mathbf{A}\end{array}$ & $\begin{array}{l}2 \\
1\end{array}$ & $\begin{array}{l}1262 \\
1054\end{array}$ \\
\hline 9 & JS & 48 & 23 & $125 / 13$ & $125 / 85$ & $\begin{array}{l}\mathbf{B} \\
\mathbf{A}\end{array}$ & $\begin{array}{l}1 \\
0\end{array}$ & $\begin{array}{l}922 \\
648\end{array}$ \\
\hline 10 & MT & 32 & 20 & $140 / 4$ & $140 / 70$ & $\begin{array}{l}\mathbf{B} \\
\mathbf{A}\end{array}$ & $\begin{array}{l}2 \\
4\end{array}$ & $\begin{array}{l}1330 \\
1242\end{array}$ \\
\hline 11 & NS & 49 & 18 & $156 / 8$ & $148 / 82$ & $\begin{array}{l}\mathbf{B} \\
\mathbf{A}\end{array}$ & $\begin{array}{l}3 \\
3\end{array}$ & $\begin{array}{l}2188 \\
2119\end{array}$ \\
\hline 12 & JD & 16 & 14 & $156 / 14$ & $156 / 86$ & $\begin{array}{l}\mathbf{B} \\
\mathbf{A}\end{array}$ & $\begin{array}{l}3 \\
2\end{array}$ & $\begin{array}{r}1050 \\
805\end{array}$ \\
\hline 13 & $\mathbf{B E}$ & 28 & 23 & $160 / 5-10$ & $185 / 90$ & $\begin{array}{l}\mathbf{B} \\
\mathbf{A}\end{array}$ & $\frac{3}{0}$ & 1553 \\
\hline 14 & DP & 26 & 16 & $135 / 5$ & $145 / 95$ & $\begin{array}{l}\mathbf{B} \\
\mathbf{A}\end{array}$ & $\begin{array}{l}0 \\
4\end{array}$ & $\begin{array}{l}1242 \\
1548\end{array}$ \\
\hline
\end{tabular}

* =Equivalent to left atrial pressure.

All vascular pressures in $\mathbf{m m H g}$. Conversion to $\mathrm{SI}$ units $\times \mathbf{0 . 1 3 3}$.

Pulmonary congestion score: $0=$ none, $1=$ doubtful, $2=$ mild (prominent upper lobe vessels, reduced lower lobe vessels), $3=$ moderate (more marked prominence of upper lobe vessels and reduction of lower lobe vessels, $4=$ severe (Kerley's lines, pulmonary oedema).

Reference level for pressures $=$ midchest. 
Clinical details of the patients are presented in table 1. All patients had undergone cardiac catheterisation shortly before the initial study, and the haemodynamic information obtained is given in table 2 . No haemodynamic data are available at time of follow-up. At each study a short history was obtained and a P-A chest film taken unless there was a recent film available. Fast and slow vital capacity (VC), inspiratory capacity (IC), and expiratory reserve volume (ERV) were measured with a nine litre Godart spirometer. Predicted values for all volumes were taken from Bates et al. ${ }^{9}$ Functional residual capacity (FRC) was measured using a nitrogen washout method (Med Science Electronics Nitralyser 305 AR, Sanborn low level preamplifier 350-1500), calibrated with gas containing $\mathbf{7 . 9} \%$ nitrogen (Scholander determined).

A $10 \mathrm{~cm}$ oesophageal balloon ${ }^{10}$ was placed with its tip $10 \mathrm{~cm}$ from the oesophago-gastric junction. The balloon contained a gas volume of $0.5 \mathrm{ml}$, at which it exerted zero pressure. Pressure difference between oesophagus and mouth was measured using a Hewlett-Packard 267-BC differential pressure transducer.

Air flow at the mouth was measured by a Sanborn pneumotachograph (A-300; 651-267c), connected to a Hewlett-Packard 270 differential pressure transducer. The voltage response of the pneumotachograph was linear in the flow range 0-5 1/s. At each study the flow channel (Sanborn carrier preamp $350-1100 \mathrm{~B}$ ) was calibrated by passing a single known flow through the pneumotachograph head, and calibration was checked at the end of each study. Flow was integrated electronically to give volume (Sanborn integrator preamplifier 350-3700), and calibrated by passing a known volume through the pneumotachograph. It was checked that the accuracy of integration was not influenced by increasing flow rate up to $21 / \mathrm{s}$.

Measurements of dynamic compliance and resistance were made according to the method of Frank et al, ${ }^{11}$ mean values for 10 representative breaths being taken. Measurements of the static volume-pressure properties of the lungs during deflation were made. ${ }^{10}$ Static tidal compliance was taken as the slope of the static P-V deflation line for one litre above FRC. The relationship between pulmonary conductance (GL) and the static recoil pressure (Pst/1) was determined at each study. ${ }^{12}$ Gas flow was interrupted by obstructing the mouthpiece with a solenoid valve. One second interruptions were made at total lung capacity (TLC) and during deflation, on the third of three maximum breaths. Expiration was quiet and not forced except below FRC. Pulmonary conductance was calculated during deflation by relating the flow at the moment of interruption to the change in transpulmonary pressure (PL). $G L=V / \Delta P L$. Conductance was plotted against transpulmonary pressure (PL) measured during the interruption, and the regression lines obtained were extrapolated to cross the $\mathrm{X}$ axis. Correlation between conductance and static transpulmonary pressure was statistically significant in all cases (in five, $\mathrm{p}<0.05$, in the remainder $\mathrm{p}<0.001$ ). The calculation of conductance was difficult in these patients because of the combination of marked cardiac pressure oscillations and small pressure changes on interruption. Mean pressure tracings were drawn by eye through the cardiac oscillations. The range of transpulmonary pressures over which conductance was measured was from $11.5 \pm 2.4$ $\mathrm{cmH}_{2} \mathrm{O}$ (mean $\pm \mathrm{SD}$ ) to $-0.96 \pm 4.3 \mathrm{cmH}_{2} \mathrm{O}$ before operation and from $12.9 \pm 3.8 \mathrm{cmH}_{2} \mathrm{O}$ to $0.93 \pm$ $2.3 \mathrm{cmH}_{2} \mathrm{O}$ after operation. Points for conductance at negative transpulmonary pressures were included in eight patients before and in only two patients after operation.

Chest radiographs were covered so that the observer could not see whether a prosthetic valve was present, and examined in random order for heart size by one of us (MJM), and for the presence of pulmonary congestion by two independent observers not otherwise involved in this study-one a radiologist and the other a cardiologist. An approximation of heart volume was made using Jonsell's formula ${ }^{13}$ : $1 \times b \times d \times 0.42$ where $1(\mathrm{~cm})$ is long diameter of heart, and $b(\mathrm{~cm})$ is broad diameter of heart, on P-A film. In this study broad diameter is taken again to approximate the depth (d), as lateral films were not available at follow-up. The constant 0.42 was derived for radiographing with a film focus distance of 1.5 metres, and includes correction for magnification.

Significance of statistical results was determined from tables in Fisher and Yates, ${ }^{14} t$ test for paired samples being applied to the data.

\section{Results}

The results of standard spirometric and lung volume indices of pulmonary function are given in table 3. Mean data for the whole group show that vital capacity (VC) and forced expiratory volume in one second $\left(\mathrm{FEV}_{1}\right)$ did not change but that RV, FRC, and TLC all increased after valve replacement. In the six aortic patients there was no significant change in FRC, but TLC and RV both 
Table 3 Lung volumes

\begin{tabular}{|c|c|c|c|c|c|c|c|c|c|c|}
\hline & \multicolumn{2}{|c|}{ Vital capacity } & \multicolumn{2}{|c|}{$\begin{array}{l}\text { Functional residual } \\
\text { capacity }\end{array}$} & \multicolumn{2}{|c|}{ Residual volume } & \multicolumn{2}{|c|}{ Total lung capacity } & \multicolumn{2}{|c|}{$\begin{array}{l}\text { Forced expired volume } \\
\text { in one second }\end{array}$} \\
\hline & $\begin{array}{l}\text { Litres } \\
\text { BTPS }\end{array}$ & $\begin{array}{l}\% \\
\text { predicted }\end{array}$ & $\begin{array}{l}\text { Litres } \\
\text { BTPS }\end{array}$ & $\begin{array}{l}\% \\
\text { predicted }\end{array}$ & $\begin{array}{l}\text { Litres } \\
\text { BTPS }\end{array}$ & $\begin{array}{l}\% \\
\text { predicted }\end{array}$ & $\begin{array}{l}\text { Litres } \\
\text { BTPS }\end{array}$ & $\begin{array}{l}\% \\
\text { predicted }\end{array}$ & $\begin{array}{l}\text { Litres } \\
\text { BTPS }\end{array}$ & $\%$ \\
\hline \multirow{3}{*}{$\begin{array}{l}\text { Before valve } \\
\text { replacement } \\
\text { After valve } \\
\text { replacement }\end{array}$} & \multicolumn{2}{|c|}{$* 3.20 \pm 0.8790$} & \multicolumn{2}{|c|}{$2.68 \pm 0.4687$} & \multicolumn{2}{|c|}{$1 \cdot 71 \pm 0.43102$} & \multicolumn{2}{|c|}{$4.91 \pm 0.8493$} & \multicolumn{2}{|c|}{$2 \cdot 34 \pm 0 \cdot 7686$} \\
\hline & \multicolumn{2}{|c|}{$3 \cdot 23 \pm 1 \cdot 1089$} & \multicolumn{2}{|c|}{$3.03 \pm 0.6899$} & \multicolumn{2}{|c|}{$2 \cdot 14 \pm 0.41124$} & \multicolumn{2}{|c|}{$5 \cdot 37 \pm 1 \cdot 27102$} & \multicolumn{2}{|c|}{$2 \cdot 39 \pm 0.9986$} \\
\hline & \multicolumn{2}{|l|}{ NS } & \multicolumn{2}{|c|}{$p<0.05$} & \multicolumn{2}{|c|}{$\mathrm{p}<0.02$} & \multicolumn{2}{|l|}{$\mathrm{p}<0.05$} & \multicolumn{2}{|l|}{ NS } \\
\hline
\end{tabular}

increased significantly $(\mathrm{p}<0.05)$. When the eight mitral patients are taken alone there was no significant change in RV, TLC, or FRC. Adding the mitral patients to the aortic made the increase in RV more significant than when aortic patients were considered on their own, and similarly putting the mitral patients with the aortic made the increase in FRC statistically significant. The significance of the increase in TLC remained unchanged by adding the mitral patients $(p<0.05)$.

There was a significant increase in static deflation compliance for the whole group (table 4). This increase in static deflation compliance was significant in the aortic $(p<0.05)$ but not in the mitral $(p<0.2)$ groups considered separately. It can be seen from inspection of the pressurevolume deflation curves (figs 1,2 ) that deflation tidal compliance did not increase just because of the changed volume at which it is measured (FRC). After operation the aortic patients (fig 1) showed a shift to the left and a decreased recoil at all lung volumes (except patient 6). In the mitral patients (fig 2 ), there was no uniform pattern. In patients 7 and 8 , there was decreased recoil at high lung volumes and increased recoil at low lung volumes after operation. Patients 10 and 11 also showed crossing of $P-V$ curves though without change in lung volumes. Patient 9 showed a shift of P-V curve to the left, and patients 12, 13 , and 14 showed decrease in compliance.

There was a tendency for the shape of the P-V deflation curve, as well as for the position, to

Table 4 Lung mechanics

\begin{tabular}{|c|c|c|c|}
\hline & \multicolumn{2}{|l|}{ Dynamic } & \multirow{2}{*}{$\begin{array}{l}\text { Static } \\
\text { Deflation } \\
\text { tidal compliance } \\
\left(\mathrm{l} / \mathrm{cm} \mathrm{H}_{2} \mathrm{O}\right)\end{array}$} \\
\hline & $\begin{array}{l}\text { Expiratory } \\
\text { flow resistance } \\
\left.\mathrm{cm} \mathrm{H}_{2} \mathrm{O} / I / s\right)\end{array}$ & $\begin{array}{l}\text { Tidal } \\
\text { compliance } \\
\left(\mathrm{I} / \mathrm{cm} \mathrm{H}_{2} \mathrm{O}\right)\end{array}$ & \\
\hline $\begin{array}{l}\text { Before operation } \\
\text { After operation }\end{array}$ & $\begin{array}{l}* 4 \cdot 72 \pm 3 \cdot 16(\mathrm{SD}) \\
4 \cdot 28 \pm 2 \cdot 55 \\
\text { NS }\end{array}$ & $\begin{array}{l}0.129 \pm 0.050 \\
0 \cdot 122 \pm 0.040 \\
\text { NS }\end{array}$ & $\begin{array}{l}0.192 \pm 0.079 \\
0.257 \pm 0.117 \\
p<0.02\end{array}$ \\
\hline
\end{tabular}

*Mean \pm SD

Conversion to SI units: resistance $\div \mathbf{9 \cdot 8}$, compliance $\times \mathbf{9 \cdot 8}$.

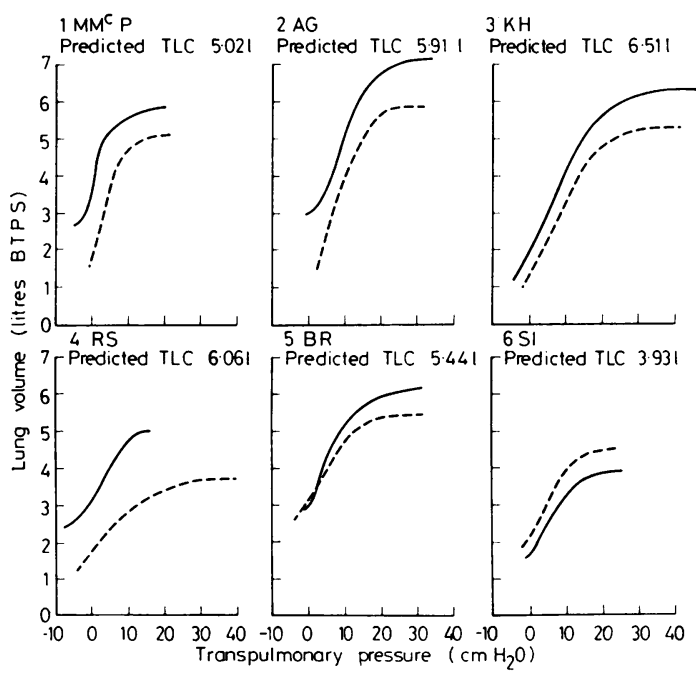

Fig 1 Static pressure-volume deflation curves in six patients before (---) and after (-) aortic valve replacement. Conversion factor to $\mathrm{SI}$ units: $\mathrm{CmH}_{2} \mathrm{O}$ $\div 9 \cdot 8$.

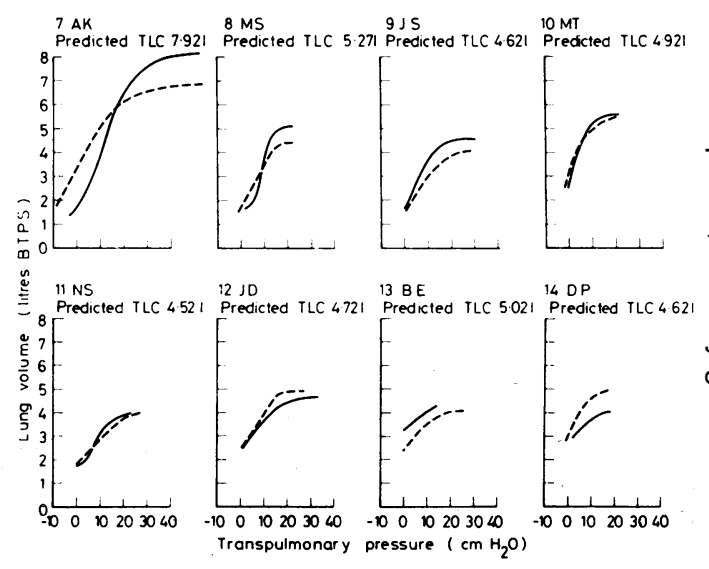

Fig 2 Static pressure-volume deflation curves in eight patients before (..) and after (-) mitral valve replacement. Conversion factor as in fig 1 . 
Table 5 Regression of conductance on transpulmonary pressure

\begin{tabular}{|c|c|c|c|c|c|}
\hline & $\begin{array}{l}\text { Conductance slope } \\
\left(\mathrm{l} / \mathrm{s} / \mathrm{CmH}_{2} \mathrm{O}\right)\end{array}$ & $\begin{array}{c}Y \text { intercept } \\
\left(\mathrm{l} / \mathrm{s} / \mathrm{cm} \mathrm{H}_{2} \mathrm{O}\right)\end{array}$ & $\begin{array}{l}\text { Pulmonary } \\
\text { conductance at } 5 \mathrm{~cm} \\
\left(\mathrm{l} / \mathrm{s} / \mathrm{cmH}_{2} \mathrm{O}\right)\end{array}$ & $\begin{array}{l}\text { Transpulmonary } \\
\text { pressure at } \\
\text { functional residual } \\
\text { capacity } \\
\left(\mathrm{CmH}_{2} \mathrm{O}\right)\end{array}$ & $\begin{array}{l}X \text { intercept } \\
\left(\mathrm{cmH}_{\mathrm{z}} \mathrm{O}\right)\end{array}$ \\
\hline *Normal values & $0.061 \pm 0.018 \dagger$ & $0.107 \pm 0.038$ & $0 \cdot 368 \pm 0.102$ & $4 \cdot 76 \pm 1 \cdot 33$ & $-1.297 \pm 1.574$ \\
\hline Before operation & $0.026 \pm 0.013$ & $0.120 \pm 0.094$ & $0 \cdot 24 \pm 0 \cdot 14$ & $2 \cdot 850 \pm 2 \cdot 70$ & $-5 \cdot 51 \pm 4.62$ \\
\hline After opzration & $\begin{array}{l}0.040 \pm 0.020 \\
\mathrm{p}<0.01\end{array}$ & $\begin{array}{l}0.037 \pm 0.036 \\
p<0.05\end{array}$ & $\begin{array}{l}0.24 \\
\text { NS }\end{array} \pm 0.14$ & $\begin{array}{l}3 \cdot 580 \pm 3 \cdot 53 \\
\text { NS }\end{array}$ & $\begin{array}{l}-1.76 \pm 3.76 \\
-\end{array}$ \\
\hline
\end{tabular}

*Conductance data on 10 normal subjects aged 20-60 years. $X$ intercepts were obtained by extrapolating regression lines.. $\nmid$ Mean $\pm S D$.

$P$ values refer to the difference between before and after operation. Conversion to SI units: conductance $\times 9 \cdot 8$, transpulmonary pressure $\div 9 \cdot 8$.

have changed. There was an increase in the slope in the tidal range. There was also a change in shape at the lower end of the curve. In some patients before operation the curve tended to be exponential throughout while after operation the curve was more sigmoid in shape, as it is in normal subjects. This shape change from a single exponential curve to a sigmoid one was most obvious in patients $1,2,4,5,7,8$, and 11 .

The slope of the regression line of conductance on static transpulmonary pressure (table 5) increased in 11 of the patients, in two of whom this was statistically significant (one at the $1 \%$ level and one at the $5 \%$ level). In one patient a large decrease that was significant at the $5 \%$ level had taken place (patient 14). Overall there was a significant increase in the mean conductancepressure slope and a significant shift of the $Y$ intercept. No statistical conclusions can be drawn about the change in position of the $\mathrm{X}$ intercepts produced by extrapolating the conductance regression lines to the $\mathrm{X}$ axis. These $\mathrm{X}$ intercepts are beyond the range of the data, and moreover as conductance was regressed on transpulmonary pressure rather than vice versa, one can correctly only make statements about values of conductance at certain values of transpulmonary pressure. However there is a trend for the $\mathrm{X}$ intercepts to shift to the right after operation (seven patients showed a shift to the right of $X$ intercepts after operation). Two representative graphs are shown in fig 3 . These results were internally consistent in that patient 14 (fig 4) showed the reverse changes-her cardiac condition deteriorated after operation with heart size increased and pulmonary congestion score rising from 0 to 4 . The V-P curve has shifted to the right, compliance has decreased, the slope of the conductance on transpulmonary pressure regression line has decreased, and the $X$ intercept, when the regression line is extrapolated, has moved to the left.

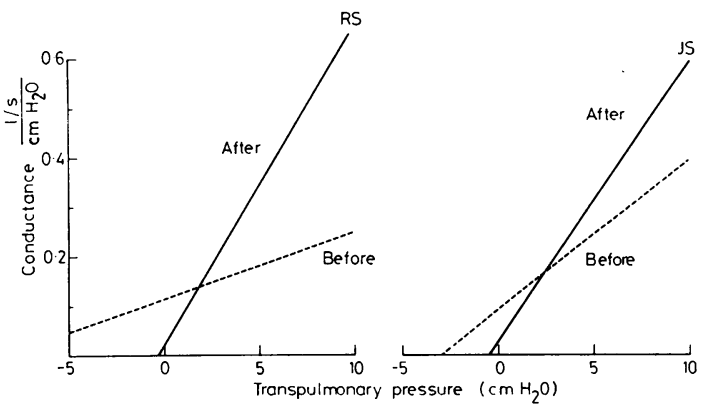

Fig 3 Representative graphs of regression of conductance on transpulmonary pressure from two patients before ( - - ) and after (-) valve surgery. Conversion factors to SI units: transpulmonary pressure $\mathrm{cmH}_{2} \mathrm{O} \div .9 \cdot 8$, conductance $\mathrm{l} / \mathrm{s} / \mathrm{cmH}_{2} \mathrm{O} \times 9 \cdot 8$.

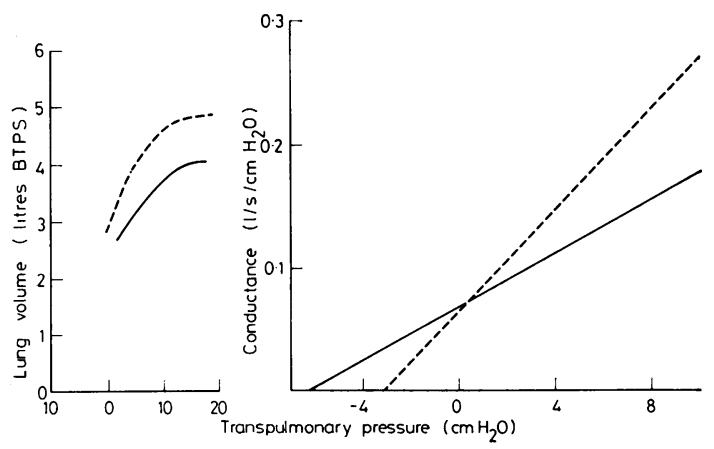

Fig 4 Pressure-volume deflation curves, and graph of regression of conductance on transpulmonary pressure measured before (-..) and after (-) mitral valve replacement in patient 14 . Reverse changes are seen to those shown by the other patients. Conversion factors as in fig 3.

\section{Discussion}

Figures 1 and 2 illustrate the similarities and differences of the lung volumes and elastic behaviour 
of the lungs between these aortic and mitral patients after valve replacement. In the aortic patients there is a fairly uniform response of increase in lung volumes, loss of elastic recoil, and in some, improvement in compliance. In the mitral patients a whole spectrum of response is shown, from improvement through little change to deterioration.

Patients were selected for this study simply on the basis that single aortic or mitral valve replacement was planned. In aortic valve disease symptoms such as breathlessness caused by left ventricular failure, angina, or syncope are relatively urgent indications for surgery. One would expect the lungs of patients with aortic disease to have been subject to a relatively short time of pulmonary congestion which may have been intermittent. In mitral disease pulmonary congestion occurs early and is unremitting, and the decision to proceed to valve replacement is difficult. Operation is usually undertaken to relieve unacceptable shortness of breath, and it may not be done for many years.

In this study in both the aortic and mitral patients the changes seen in pressure-volume curves may be attributed to lessening pulmonary congestion or oedema or both. The lack of change in some mitral patients may have been the result either of the failure of the operation to lower haemodynamic pressures and relieve congestion, or of irreversible secondary effects on the lung such as fibrosis. In this study the mitral patients whose lung mechanics improved most were a man of 26 years with mitral stenosis (patient 7), a man of 45 years with mitral incompetence (patient 8), and a woman of 55 years who had had recent onset of mitral incompetence (patient 9). The other five patients, women aged 48-61 years, with symptoms of dyspnoea ranging in duration from six months to 24 years, showed little or no improvement in lung mechanics. It is interesting that all claimed some lessening of dyspnoea. The question arises as to whether there is a place for early operation in mitral disease to prevent development of irreversible lung damage.

The other difference in pattern of pressurevolume curves was that some of the curves of the mitral patients before and after operation crossed (figs 1,2). This has been shown to occur when comparing patients with mitral disease with normal subjects. ${ }^{15} 16$ This difference between the aortic and mitral patterns may be in part related to the fact that in these aortic patients there was a more marked reduction in heart size (mean decrease in heart volume index $=258 \mathrm{ml}$ ) than in most of the

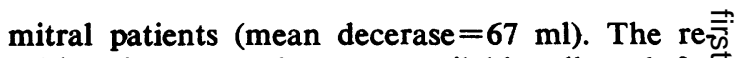
sulting increase of space available allowed foto bigger residual lung volumes after operation and so pushed the curves further apart.

The differing response to operation of volume-क्ष pressure relationships in these aortic and mitrah patients is probably related to the effects of dif $=$ ferent duration and perhaps severity of pulmon? ary congestion, rather than to any intrinsic dif $\overrightarrow{\vec{H}}$ ference between the pulmonary congestion of aortic disease and that of mitral disease. There is some evidence of merging of these two patterns ${ }_{\omega}$ In patient 5 with aortic stenosis and incompetence the curve after operation crossed that of the firste study, and conversely mitral patient 9 , who was known to have had sudden onset of mitral incom? petence from rupture of a valve support one year before, had curves which did not cross.

It is informative to look at conductance over the whole vital capacity, as is done in considering the conductance transpulmonary pressure relation 00 ships (fig 3). It appears that before operation con:ductance was better at low lung volumes anc worse at high lung volumes than after operation This means that in the tidal range, depending on the volume at which these lines cross, conductance्ष will be better, worse, or unchanged after opera $\underline{\Omega}$ tion. However when a bigger breath is taken, con $\overrightarrow{\vec{B}}$ ductance at higher lung volumes is improved by the relief of congestion and oedema. One inter pretation of these conductance pressure relation ships is that in the chronically oedematous state airways behave as rigid tubes, less distensible a high lung volumes and less compressible at low lung volumes.

The inflection point in sigmoid pressure-volumes curves has been shown mathematically by Glaister $e t a l^{17}$ to occur at the transpulmonaryo pressure at which apparent airway closure begins If closure of air spaces occurred simultaneouslyo at RV then the curve would be exponentia throughout its length. ${ }^{18}$ The inflection point has been shown experimentally in excised anima 0 lungs ${ }^{17}$ and in healthy human subjects ${ }^{1920}$ to occur at a volume which approximates to closing ca-o pacity (volume at which airway closure begins). It has been noted that in those patients subject tof longstanding congestion the inflection point iș absent in some before operation and present aftero operation. This suggests that in the chronically $\vec{P}_{\vec{P}}$ congested state, closure of airways occurs later in expiration than after operation when congestion $\mathbb{Q}$ has been relieved at least partially. This suggestiono of a decrease in closing volume (closing capacity minus RV) is at variance with work in congestion 
of recent origin. ${ }^{124}$ Closing volumes were not measured in this study because it was not anticipated that this suggestion would emerge from the data.

Some support for this concept of chronically congested airways resisting airway closure is found on looking at the conductance-pressure regression lines. The $\mathrm{X}$ intercept formed by extrapolating the line to zero conductance theoretically represents the transpulmonary pressure at which conductance is zero. In chronic pulmonary congestion before operation the intrapleural pressures at which conductance is zero are more positive than after operation. This again suggests that chronically congested airways resist closure, and may be one reason why residual volume is lower before operation.

The apparent paradox, seen in some of these mitral patients before operation, of stiffer lungs but with less elastic recoil as is seen at low lung volumes, has previously been attributed to the support given to alveolar walls by engorged vasculature. ${ }^{91621}$ It may be that in the congested state at low lung volumes near $\mathrm{RV}$, more airways are open, so more lung units are participating. In such a situation each alveolus can be less distended with subsequent less recoil, to give the same total lung volume. When normal airway closure is occurring the fewer participating units need to be more distended, and hence have more recoil, at the same lung volume.

These data from 14 patients with longstanding pulmonary congestion studied before operation and again one to two years after congestion had been relieved in most of them, show differences from experimental models and clinical cases of acute pulmonary congestion as well as some similarities. After valve replacement more space is made available within the chest by the decrease in heart size, relief of congestion, and removal of oedema, and in addition removal of oedema results in more compliant alveoli, and more normal distensibility of airways.

This work was supported in part by a grant from St Vincent's Hospital, Melbourne, and St Vincent's School of Medical Research Grants Committee. We are grateful to $\mathrm{Dr}$ Ian MacDonald and $\mathrm{Dr}$ John McCosker who kindly scored the chest radiographs for pulmonary congestion. We would also like to thank $\mathrm{Mr}$ John Clareborough and $\mathrm{Mr}$ George Westlake for permission to study their patients and Dr Ian MacDonald for suggesting this topic for study.

\section{References}

1 Collins JV, Cochrane GM, Davis J, Benatar SR, Clark TJH. Some aspects of pulmonary function after rapid saline infusion in healthy subjects. Clin Sci Mol Med 1973; 45:407-10.

2 Muir AL, Flenley DC, Kirby BJ, Sudlow MF, Guyatt AR, Brash HM. Cardiorespiratory effects of rapid saline infusion in normal man. $J A p p l$ Physiol 1975; 38:786-93.

3 Wilhemsen L, Varnauskas E. Effects of acute plasma expansion on the mechanics of breathing. Clin Sci 1967; 33:29-38.

4 Hales CA, Kazemi H. Small-airways function in myocardial infarction. $N$ Engl J Med 1974; 290: 761-5.

5 Donald KW, Bishop JM, Wade OL, Wormald PN. Cardiorespiratory function two years after mitral valvotomy. Clin Sci 1957; 16:325-50.

6 Saxton GA, Rabinowitz M, Dexter L, Haynes F. The relationship of pulmonary compliance to pulmonary vascular pressures in patients with heart disease. J Clin Invest 1956; 35:611-8.

7 Singh T, Dinda P, Chatterjee SS, Riding WD, Patel TK. Pulmonary function studies before and after closed mitral valvotomy. Am Rev Respir Dis 1970; 101:62-6.

8 Williams MH Jr. Pulmonary function studies in mitral stenosis before and after commissurotomy. J Clin Invest 1953; 32:1094-6.

9 Bates DV, Macklem PT, Christie RV. Respiratory function in disease. Second edition. Philadelphia: Saunders, 1971:93-4.

10 Milic-Emili J, Mead J, Turner JM, Glauser EM. Improved technique for estimating pleural pressure from eosophageal balloons. J Appl Physiol 1964; 19:207-11.

11 Frank NR, Mead J, Ferris BG. The mechanical behavior of the lungs in healthy elderly persons. J Clin Invest 1957; 36:1680.

12 Colebatch HJH, Finucane KE, Smith MM. Pulmonary conductance and elastic recoil relationships in asthma and emphysema. J Appl Physiol 1973; 34:143.

13 Jonsell SA. A method for the determination of the heart size by teleroentgenography (a heart volume index). Acta Radiol (Stockh) 1939; 20: $325-40$.

14 Fisher RA, Yates F. Statistical tables for biological, agricultural and medical research. Sixth edition. Edinburgh: Oliver and Boyd, 1974.

15 Wilhelmsen L. Lung mechanics in rheumatic valvular disease. Acta Med Scand, Suppl 489, 1968.

16 Wood TE, McLeod P, Anthonisen NR, Macklem PT, Mechanics of breathing in mitral stenosis. Am Rev Respir Dis 1971; 104:52-9.

17 Glaister DH, Schroter RC, Sudlow MF, MilicEmili J. Bulk elastic properties of excised lungs and the effect of a transpulmonary pressure gradient. Respir Physiol 1973; 17:347-64. 
18 Davis JDH, Glaister DH, Schroter RC. Assessment of closure of lung units based on the pressure volume curve. J Physiol 1975; 252:30P.

19 Demedts $M$, Clement J, Stanescu DC, van de Woestijne KP. Inflection point of transpulmonary pressure-volume curves and closing volume. $J$ J Appl Physiol 1975; 38:228-35.
20 Ingram RH, O'Cain CF, Fridy WW. Simul $\overrightarrow{\vec{ल}}$ taneous quasistatic lung-pressure volume curves and "closing volume" measurements. J App Physiol 1974; 36:135-41.

21 Amyot R, Levine M, Dame J, Martin RR. Rela tionship of airway closure and pulmonary wedg® pressure in dogs. Fed Proc 1975; 34:402. 